\title{
IMMUNOCHEMICAL AND ELECTROPHORETIC PROPERTIES OF OESTROUS RABBIT UTERINE FLUID PROTEINS OBTAINED BY UTERINE LIGATION
}

\author{
K. R. STEVENS*, H. D. HAFS and A. G. HUNTER $\dagger$ \\ Department of Dairy, Michigan State University, \\ East Lansing, Michigan, U.S.A.
}

(Received 26th March 1964)

\begin{abstract}
Summary. Fluids were obtained from 185 rabbit uteri 1 to 20 weeks after uterine ligation. The uterine fluid proteins were concentrated with an ultrafilter and characterized by diffusion in agar gel, moving boundary electrophoresis, and immunoelectrophoresis. Eight electrophoretic components were identified by means of moving boundary electrophoresis. One which migrated as a pre-albumin and another which migrated as an alpha-globulin were not found in blood sera. Agar-gel diffusion tests revealed thirteen antigenic components in uterine fluid. Three precipitin lines appeared to be specific to uterine fluid after absorption of guinea-pig antisera to rabbit uterine fluid with rabbit blood sera. However, at least five antigens which could not be found in blood sera were identified in uterine fluid by means of immunoelectrophoresis. The mobilities of two were similar to prealbumins and the mobilities of the remaining three were similar to beta-globulins. The results indicated that at least two classes of proteins, which do not exist in rabbit blood serum, may be found in uterine fluids obtained by ligation.
\end{abstract}

\section{INTRODUGTION}

Woskressensky (1891) observed fluid accumulations in rabbit uteri which were ligated at both extremities. That observation has been repeatedly confirmed (Stevens, Hafs \& Kirton, 1964). Shih, Kennedy \& Huggins (1940) reported the concentrations of several inorganic ions and protein in fluids from ligated rabbit uteri. Heap (1962) concluded that ligation of the uterus altered the ratio of several biochemical components in rabbit uterine fluid. However, Albers \& Neves e Castro (1961) found no difference in the antigenic components of fluids from ligated or unligated uteri of rats, a species in which uterine fluids normally accumulate at oestrus.

Studies of rat uterine fluids by moving boundary (Junge \& Blandau, 1958; Ringler, 1961), paper (Junge \& Blandau, 1958) and immunoelectrophoresis

* Present address: Department of Animal Science, University of Illinois, Urbana, Illinois, U.S.A.

$\dagger$ Present address: Department of Dairy Husbandry, University of Minnesota, St. Paul, Minnesota, U.S.A. 
(Albers \& Neves e Castro, 1961) revealed four or five protein components in uterine fluid. A component which resembled pre-albumin and another which resembled beta-globulin were peculiar to uterine fluid in that they were not found in rat blood serum.

Lutwak-Mann (1962) recovered 0.1 to $2 \cdot 0 \mathrm{ml}$ of rabbit uterine fluid at 5 to $24 \mathrm{hr}$ after ovulation without uterine ligation. Oestrous rabbit uteri accumulated fluid at rates of 2.10 to $4.48 \mathrm{ml} /$ cornu/week for as long as 20 weeks after uterine ligation (Stevens et al., 1964). The protein content of the latter fluids ranged from 1.82 to $5.13 \mathrm{mg} / \mathrm{ml}$-values considerably less than those characteristic of blood serum. The low protein content of uterine fluids relative to blood serum is also characteristic of the other species which have been studied (reviewed by Stevens et al., 1964).

The purpose of the present research was to characterize the proteins in oestrous rabbit uterine fluids by electrophoretic and immunochemical techniques. Because the low protein content of uterine fluids and the small volumes of uterine fluids normally recoverable precluded some of the desired analytical procedures, uterine fluids were obtained from ligated uteri for these experiments.

\section{METHODS}

One hundred and eighty-five oestrous rabbit (Dutch type) uteri were ligated at the cervical or at both extremities with synthetic suture, and the fluids in the uterine lumina were aspirated after accumulation for 1 to 20 weeks according to procedures previously described (Stevens et al., 1964). Uterine fluids were pooled according to duration of uterine ligation. The proteins were concentrated in an ultrafilter ( $\mathrm{LKB}$, model $6300 \mathrm{~A})$ to a final concentration of $2 \%$, based upon the biuret method of Gornall, Bardawill \& David (1949).

Rabbit blood serum and concentrated uterine fluid from each accumulation interval were dialysed for $24 \mathrm{hr}$ with constant agitation against two changes of barbital buffer ( $\mathrm{pH} 8 \cdot 6, \mu 0 \cdot 10$ ), each being approximately one hundred times the volume of serum or fluid. Electrophoresis was performed at $15 \mathrm{~mA}$ for 150 min at $2^{\circ}$ Cin a Tiselius apparatus (American Instrument Co., Inc., Silver Spring, Maryland, U.S.A.) and migration was recorded photographically. Mobilities of electrophoretic components were estimated by the method of Alberty (1948), and the relative concentrations of the components were estimated by the method of Tiselius \& Kabat (1939).

Antisera to concentrated uterine fluids and to rabbit blood sera were produced by intradermally injecting an emulsion of $0.5 \mathrm{ml}$ of antigen and $0.5 \mathrm{ml}$ of Freund's complete adjuvant into the scapular region of each of six guinea-pigs. Two weeks later each guinea-pig was injected with an emulsion of the same antigen and Freund's incomplete adjuvant. The guinea-pigs were bled by cardiac puncture 2 weeks after the second injection and the antisera were collected and stored at $-20^{\circ} \mathrm{C}$.

Diffusion-in-gel was used to test guinea-pig antisera for precipitins according to the method of Ouchterlony (1958), and absorption tests were performed according to the method of Björklund (1952) to identify uterine fluid-specific proteins. The agar (agar agar No. 3, Consolidated Laboratories, Inc., Chicago, 
Illinois, U.S.A.) was dissolved $(0.85 \%)$ in $0.005 \mathrm{~m}$-phosphate buffered (pH 7.4) saline $(0.85 \%)$, and merthiolate $(0.001 \%)$ was added to retard bacterial growth. Diffusion was allowed for 3 weeks at $5^{\circ} \mathrm{C}$, after which no new precipitin lines developed. The Ouchterlony plates were photographed at suitable intervals to record precipitin line formation. Discontinued plates were fixed, washed, dried and stained with amidoschwartz according to Crowle (1961).

Immunoelectrophoresis was performed by methods modified from Wieme (1959). The concentrated uterine fluid proteins were dialysed against barbital buffer ( $\mathrm{pH} \mathrm{8.4, \mu} \mathrm{0.05)} \mathrm{prior} \mathrm{to} \mathrm{electrophoresis.} \mathrm{Microscope} \mathrm{slides}(75 \times 50 \times 1$ $\mathrm{mm}$ ) were covered with $2 \mathrm{~mm}$ of $0.85 \%$ agar agar No. 3 dissolved in barbital

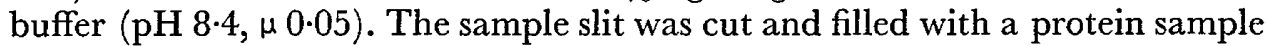
immediately before electrophoresis. A potential of 150 volts with a maximum

TABLE 1

ELECTROPHORETIC MOBILITIES* OF PROTEINS IN UTERINE FLUID AND BLOOD SERUM

\begin{tabular}{|c|c|c|c|c|c|c|c|c|c|}
\hline \multirow{2}{*}{ Sample } & \multirow{2}{*}{$\begin{array}{l}\text { Weeks of } \\
\text { accumulation }\end{array}$} & \multicolumn{8}{|c|}{ Electrophoretic component } \\
\hline & & 1 & 2 & 3 & 4 & 5 & 6 & 7 & 8 \\
\hline Uterine fluid & $\begin{array}{r}1-2 \\
1-2 \\
1-2 \\
5 \\
7 \\
16 \\
20\end{array}$ & $\begin{array}{l}1.6 \\
1.8 \\
1.8 \\
2.3 \\
2.1 \\
1.5 \\
-\end{array}$ & $\begin{array}{l}2.9 \\
3.0 \\
3.0 \\
3.3 \\
3.0 \\
2.7 \\
3.2\end{array}$ & $\begin{array}{l}3.5 \\
3.6 \\
3.8 \\
4.0 \\
3.9 \\
3.5 \\
3.8\end{array}$ & $\begin{array}{l}4 \cdot 5 \\
4 \cdot 5 \\
4 \cdot 8 \\
4 \cdot 8 \\
4 \cdot 2 \\
4 \cdot 9\end{array}$ & $\begin{array}{l}5 \cdot 1 \\
5 \cdot 1 \\
- \\
5 \cdot 2 \\
4 \cdot 8 \\
-\end{array}$ & $\begin{array}{l}5 \cdot 7 \\
5 \cdot 6 \\
5.8 \\
5.8 \\
5.8 \\
5.8 \\
6.1\end{array}$ & $\begin{array}{l}6 \cdot 9 \\
6 \cdot 8 \\
7 \cdot 4 \\
7 \cdot 3 \\
6 \cdot 8 \\
6 \cdot 6 \\
7 \cdot 0\end{array}$ & $\begin{array}{l}\text { 二 } \\
\text { 二 } \\
\overline{7.8} \\
7.8 \\
7.9\end{array}$ \\
\hline Blood serum & E & $\begin{array}{l}1.5 \\
1.4 \\
1.6\end{array}$ & $\begin{array}{l}2 \cdot 3 \\
2 \cdot 4 \\
2 \cdot 9\end{array}$ & $\begin{array}{l}3 \cdot 5 \\
3.7 \\
3.6\end{array}$ & $\begin{array}{l}4 \cdot 3 \\
4 \cdot 5 \\
4 \cdot 9\end{array}$ & $\begin{array}{l}5 \cdot 2 \\
5 \cdot 4 \\
5 \cdot 2\end{array}$ & 二 & $\begin{array}{l}6.9 \\
7 \cdot 1 \\
6 \cdot 8\end{array}$ & 二 \\
\hline
\end{tabular}

$*\left(\mathrm{~cm}^{2} /\right.$ volt sec $)\left(\times 10^{-5}\right)$.

of $60 \mathrm{~mA}$ was applied for $30 \mathrm{~min}$. After electrophoresis, a trough $0.5 \mathrm{in}$. wide was cut $0.5 \mathrm{in}$. from the origin and parallel to the direction of electrophoretic migration. The bottom of the trough was sealed with a drop of molten agar and appropriate antiserum was added to the trough. Diffusion was allowed for about 3 weeks at $5^{\circ} \mathrm{C}$. Thereafter, no new antigen-antibody precipitation arcs could be identified. Precipitin line formation was recorded and the discontinued plates were fixed, washed, dried, and stained similarly to Ouchterlony plates.

\section{RESULTS}

Moving boundary electrophoresis demonstrated eight components in uterine fluid samples, six of which also were identified in blood sera (Table 1). One component (mean mobility $=7.8 \mathrm{~cm}^{2}$ volt ${ }^{-1} \mathrm{sec}^{-1} \times 10^{-5}$ ) was peculiar to rabbit uterine fluids obtained after 5 weeks of accumulation. Another component of uterine fluids (mean mobility $=5.8 \mathrm{~cm}^{2}$ volt ${ }^{-1} \mathrm{sec}^{-1} \times 10^{-5}$ ) also differed from any component of blood serum. The mobilities for blood serum components (Table 1) were in good agreement with similar data reported by Moore (1945) and by Deutsch \& Goodloe (1945) for rabbit blood sera. 
The relative concentrations of the electrophoretic components further demonstrated the similarity of blood sera and uterine fluids (Table 2). The sum (mean $=66 \cdot 6 \pm 0 \cdot 7$ ) of the relative concentration of Components 7 and 8 (albumin- and pre-albumin-like components, respectively) of uterine fluids was very close to the relative albumin content $(68 \%)$ of blood serum. The fluctuations in relative protein content within Components 3,4 or 5 were probably due chiefly to experimental errors. The position and small size of these components on the electrophoresis patterns made accurate concentration measurements very difficult.

TABLE 2

RELATIVE PROTEIN CONTENT (\%) OF UTERINE FLUIDS AND BLOOD SERUM

\begin{tabular}{|c|c|c|c|c|c|c|c|c|c|}
\hline \multirow{2}{*}{ Sample } & \multirow{2}{*}{$\begin{array}{c}\text { Weeks of } \\
\text { accumulation }\end{array}$} & \multicolumn{8}{|c|}{ Electrophoretic component } \\
\hline & & 1 & 2 & 3 & 4 & 5 & 6 & 7 & 8 \\
\hline Uterine fluid & $\begin{array}{r}1-2 \\
5 \\
7 \\
16 \\
20\end{array}$ & $\begin{array}{r}3 \\
3 \\
3 \\
5 \\
-\end{array}$ & $\begin{array}{l}1 \\
5 \\
4 \\
6 \\
3\end{array}$ & $\begin{array}{r}4 \\
11 \\
6 \\
2 \\
6\end{array}$ & $\begin{array}{r}6 \\
5 \\
2 \\
13\end{array}$ & $\begin{array}{r}6 \\
11 \\
3 \\
-\end{array}$ & $\begin{array}{l}11 \\
14 \\
13 \\
17 \\
13\end{array}$ & $\begin{array}{l}68 \\
67 \\
59 \\
56 \\
58\end{array}$ & $\begin{array}{l}- \\
9 \\
9 \\
7\end{array}$ \\
\hline Blood serum & - & 8 & 3 & 8 & 4 & 9 & - & 68 & - \\
\hline
\end{tabular}

The Ouchterlony plates (Pl. 1, Fig. 1) revealed at least thirteen antigens in pooled uterine fluids from each accumulation interval. Ten of these precipitin lines appeared to form identities with comparable lines for blood serum. Three uterine fluid antigens appeared to have no antigenic counterpart in blood serum. Five precipitin lines, three of which were not continuous with blood serum lines, were identified in plates in which antisera to uterine fluid had been absorbed with blood serum. Although the absorption was incomplete, this result provided additional evidence for the presence of at least three antigens peculiar to uterine fluids.

Immunoelectrophoresis confirmed the similarity between uterine fluid and blood serum proteins (Pl. 1, Fig. 2). Nineteen uterine fluid proteins were identified and at least five of these did not appear in blood serum. The mobilities of two uterine fluid-specific proteins were similar to pre-albumins and the mobilities of at least three were similar to beta-globulins. Absorption of guineapig antisera to rabbit uterine fluid with rabbit blood serum, followed by diffusion against the uterine fluid proteins that had been separated by electrophoresis, confirmed the presence of the uterine fluid-specific proteins, with mobilities similar to pre-albumins and beta-globulins.

\section{EXPLANATION OF PLATE 1}

FIG. 1. Composite drawing of typical Ouchterlony plate. Centre well contained antisera to uterine fluid (Anti-UF). Peripheral wells contained uterine fluid (UF) after 1, 4, 5, 16 or 20 weeks of accumulation. One well contained control blood serum (Bs).

FIG. 2. Composite drawing of immunoelectrophoresis plate. Uterine fluid (UF-top slit) and control blood serum (BS-bottom slit) were electrophoresed (anode at left). Centre trough was then filled with equal parts of antiserum to uterine fluid (Anti-UF) and antiserum to control blood serum (Anti-Bs). Note uterine fluid-specific components similar to pre-albumins (arrow-top, far left) and $\beta$-globulins (arrow-top, between slit and trough). 
PLATE 1

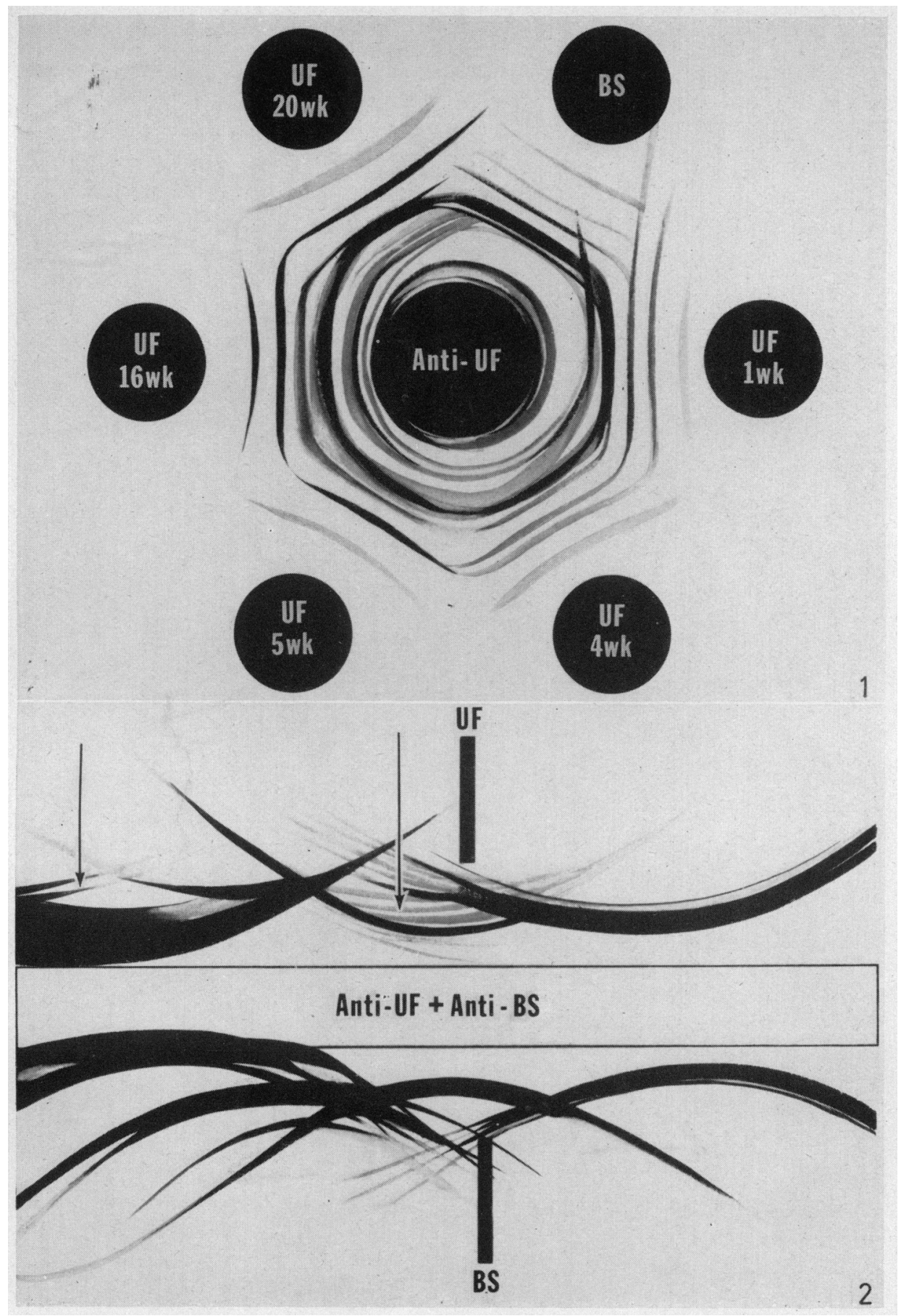

(Facing p. 322) 
All precipitin lines in Ouchterlony and immunoelectrophoresis plates stained as proteins with amidoschwartz.

\section{DISCUSSION}

Diffusion in agar gel revealed thirteen uterine fluid antigens, three of which were not found in blood serum. At least one of these precipitin lines must have been composed of more than one antigen, since separation of the uterine fluid antigens by electrophoresis prior to diffusion indicated that at least five antigens were peculiar to uterine fluids. Based upon the electrophoretic mobilities, two of the five uterine fluid-specific proteins resemble pre-albumins while the remaining three resemble beta-globulins. Experiments with rats also demonstrated uterine fluid-specific components that resembled pre-albumin (Junge \& Blandau, 1958; Ringler, 1961) and beta-globulin (Albers \& Neves e Castro, 1961; Junge \& Blandau, 1958).

The present data, in agreement with similar evidence published on rats (Ringler, 1961), indicate that the sum of the concentrations of the albuminand pre-albumin-like components in uterine fluids was close to the albumin concentration of blood serum. Moving boundary electrophoresis confirmed the presence of a component which migrated as a pre-albumin in rabbit uterine fluids that had accumulated for more than 5 weeks. Immunoelectrophoresis, however, demonstrated components which migrated as pre-albumin in fluids after all accumulation intervals. The failure of moving boundary electrophoresis to show this component in fluids accumulated for periods less than 5 weeks probably reflected the greater sensitivity of immunoelectrophoresis for this experimental material. This conclusion was supported by the failure of moving boundary electrophoresis to detect the uterine fluid-specific components which migrated as beta-globulins.

Moving boundary electrophoresis consistently demonstrated a major component which migrated as alpha globulin in uterine fluids (Component 6 ) but not in blood sera. This component could not be positively identified by immunoelectrophoresis, even when the guinea-pig antiserum to rabbit uterine fluid was absorbed with rabbit blood serum. These results suggest that the component in question has an antigenic analogue which differs electrophoretically in blood sera. Such an analogue could have resulted from alteration of a blood serum protein as it passed through the uterine tissue into the uterine lumen. Peptidases, which could be responsible for this alteration, have been identified in uterine tissue (Smith, 1948) and in uterine fluids (Albers, Bedford \& Chang, 1961). This explanation parallels that of Ringler (1961) concerning the origin of a component which resembled pre-albumin in rat uterine fluid.

The electrophoretic similarity of blood serum and uterine fluid protein components suggests that uterine fluids are derived at least partly from blood serum. Ringler (196I), in support of this hypothesis, noticed that the electrophoretic patterns of fluids from ligated rat uteri became more like those of blood serum after prolonged intervals of ligation. Sturgis (1942) found that the rate of 'secretion' of fluid in the monkey uterus paralleled the systolic pressure in the pelvic region, thus providing indirect evidence for a blood origin of uterine fluids. The present data for rabbits and those of Albers \& Neves e Castro (1961) 
for rats demonstrated the antigenic similarity of blood serum and uterine fluids and offered further support for the contention that uterine fluids are, at least in part, transudates from blood.

However, the ratios of some inorganic components in uterine secretions differed from those in blood (Howard \& De Feo, 1959; Ringler, 1961), thus providing evidence that these constituents were secretions and not transudations (Albers et al., 1961). For example, Howard \& De Feo (1959) found ten times as much potassium in rat uterine fluids as in rat blood, while the sodium concentration was slightly lower in uterine fluids than in blood.

Regardless of their origin, at least two classes of proteins exist in uterine fluid while they have not been demonstrated in blood serum.

\section{ACKNOWLEDGMENTS}

This paper is Journal Article No. 3276 from the Michigan Agricultural Experiment Station. This research was supported by National Institutes of Health Grant No. GM10584.

\section{REFERENCES}

Albers, H. J., Bedford, J. M. \& Chang, M. C. (1961) Uterine peptidase activity in the rat and rabbit during pseudo-pregnancy. Amer. F. Physiol. 201, 554.

Albers, H. J. \& Neves e Gastro, M. (1961) The protein components of rat uterine fluid. An analysis of its antigens by immunoelectrophoresis and Ouchterlony gel diffusion technique. Fertil. Steril. $12,142$.

Alberty, R. A. (1948) An introduction to electrophoresis. I. Methods and calculations. F. chem. Educ. $25,426$.

BJörKLUND, B. (1952) Specific inhibition of precipitation as an aid in antigen analysis with gel diffusion method. Proc. Soc. exp. Biol., N.Y. 79, 319.

Growle, A. J. (1961) Immunodiffusion. Academic Press, New York.

Deutsch, H. F. \& Goodloe, M. B. (1945) An electrophoretic survey of various animal plasmas. $\mathcal{F}$. biol. Chem. 161, 1.

Gornall, A. G., Bardawill, G. J. \& David, M. M. (1949) Determination of serum proteins by means of the biuret reaction. $\mathcal{7}$. biol. Chem. 177, 751 .

Heap, R. B. (1962) Some chemical constituents of uterine washings: A method of analysis with results from various species. $\mathcal{7}$. Endocrin. 24, 367.

Howard, E. \& De Feo, V. J. (1959) Potassium and sodium content of uterine and seminal vesicle secretions. Amer. J. Physiol. 196, 65.

Junge, J. M. \& Blandau, R. J. (1958) Studies on the electrophoretic properties of cornual fluids of rats in heat. Fertil. Steril. 9, 353.

Lutwak-ManN, C. (1962) Some properties of uterine and cervical fluid in the rabbit. Biochim. biophys. Acta, 58, 637.

Moore, D. H. (1945) Species differences in serum protein patterns. F. biol. Chem. 161, 21.

Ouchterlony, O. (1958) Diffusion-in-gel methods for immunological analysis. Progr. Allergy, 5, 1.

RiNGLER, I. (1961) The composition of rat uterine luminal fluid. Endocrinology, 68, 281.

Shim, H. E., Kennedy, J. \& Huggins, C. (1940) Chemical composition of uterine secretions. Amer. $\mathcal{F}$. Physiol. 130, 287.

Sмiтн, E. L. (1948) The peptidases of skeletal, cardiac, and uterine muscle. F. biol. Chem. 173, 553.

Stevens, K. R., Hafs, H. D. \& Kirton, K. T. (1964) Volume, $\mathrm{pH}$ and protein content of fluids from ligated uteri of oestrous rabbits. F. Reprod. Fertil. 7, 331.

Sturgis, S. H. (1942) Method for obtaining uterine fluid from the monkey; effect of pilocarpine, atropine, physiological salt solution and adrenaline. Endocrinology, 31, 664 .

Tiselius, A. \& Kabat, E. A. (1939) An electrophoretic study of immune sera and purified antibody preparations. $\mathcal{F}$. exp. Med. 69, 119.

Wieme, R. J. (1959) An improved technique of agar-gel electrophoresis on microscope slides. Clin. chim. Acta, 4, 317.

Woskressensky, M. A. (1891) Experimentelle untersuchungen über die pyo- und Hydrosalpinxbildung bei den Thieren. Centralblatt für Gynäkol. 15, 849. 